\title{
MANAJEMEN DAKWAH DI TENGAH PERKEMBANGAN TEKNOLOGI INFORMASI
}

\author{
OLEH \\ Suhadi S.Ag M.sos.I
}

\begin{abstract}
The development of information technology enhances the management of missionary endeavor (da'wah) because the development of information technology is able to change the mindset and attitude patterns of mankind. In this process, the principles of missionary endeavor (da'wah) management must be applied by besides giving precise meaning about the meaning of communicator, media and audience that need to be developed on broader meaning through information technology. The use of information technology to support the management of missionary endeavor (da'wah) will provide effectiveness to the flow of missionary endeavor (da'wah).
\end{abstract}

\section{PENDAHULUAN}

A. Latar Belakang

Di dalam Alquran dan Sunnah, dikemukakan bahwa dakwah menduduki tempat dan posisi sentral dan menentukan. Metode dakwah yang tidak tepat, sering memberikan gambaran dan pendapat yang keliru tentang Islam, sehingga salah langkah dalam operasional dakwah.

Oleh karena itu, penerapan dakwah perlu adanya sistem atau metode yang tepat dalam pelaksanaan operasional yang dikenal dengan menajemen dakwah. Pendekatan dan teknik yang digunakan akan mampu mencabut akar permasalahan dan tidak sekedar mengobati gejala-gejalanya.Perkembangan sains dan teknologi merupakan faktor pen-dukung dan penghambat laju perkembangan manajemen dakwah.

Sains dan teknologi di zaman modern dewasa ini memegang peranan penting dan sistem penerapannya dalam bentuk teknologi modern begitu besar, sehingga merupakan esensi yang absolut dengan kaum muslimin. Dalam kaitan ini Sayyid Hussein Nasr menyebutkan bahwa kaum muslimin harus mempelajari sains modern sebagai struktur teoritis dan penerapannya dalam berbagai bidang.

Manusia merasakan adanya suatu tuntutan untuk melakukan revolusi fundamental terhadap fungsi sains dan teknologi bagi ke-hidupannya. Perlu ada penilaian kembali secara radikal tentang arah dan perkembangan sains dan teknologi, apakah masih bersifat positif konstruktif bagi kehidupan manusia, atau justru cenderung bersifat negatif.

Dewasa ini, tidak bisa disangkal lagi bahwa penggunaan dan pemanfaatan teknologi sudah hampir ke seluruh bidang kehidupan, dari tahun ke tahun semakin meningkat, baik dari segi jumlahnya maupun dari segi kualitasnya. 
Kemajuan sains dan teknologi tersebut membawa dampak negatif bagi kehidupan manusia, baik secara langsung maupun tidak langsung.

Ada beberapa dampak negatif yang ditimbulkan oleh kemanjuan sains dan teknologi dewasa ini, misalnya: kelestarian lingkungan dan ancaman kemusnahan peradaban manusia itu sendiri. Di samping itu manusia diancam oleh konfrontasi alam yang akibatnya akan benar-benar fatal bagi kelanjutan peradaban manusia.

Perkembangan sains dan teknologi, bukan saja membawa manusia kepada kemajuan, tetapi juga kadangkala membawa manusia menjauhkan diri dari ajaran agama, di samping memiliki sisi yang sangat bermanfaat bagi hidup dan kehidupan manusia, juga mempunyai dampak negatif yang dapat merugikan dan mengancam eksistensi umat manusia dan bahkan dapat menghilangkan integritas manusia.

Efek negatif yang ditimbulkan oleh sains dan teknologi tersebut, maka manajemen dakwah diperhadapkan pada masalah yang sangat besar dan komprehensif.

Untuk itulah, manajemen dakwah tidak boleh ketinggalan dan meninggalkan sains dan teknologi guna menata masa depan, bahkan manajemen dakwah tidak boleh larut dalam masalah-masalah yang mendasar saja, tetapi harus mampu memanfaatkan dan menguasai teknologi. Masalah pokok yaitu bagaimana upaya manajeman dakwah dalam mengantisipasi dampak negatif perkembangan sains dan teknologi ?.

\section{PEMBAHASAN}

Manajemen adalah proses yang telah terdiri dari pe-rencanaan, pengorganisasian, pelaksanaan dan pengawasan yang dilakukan untuk menentukan dan mencapai tujuan yang telah ditetapkan dengan menggunakan tenaga orang dan sumber lainnya.

Manajemen dapat dipahami sebagai suatu proses yang berjalan terus pada suatu arah perbaikan dengan melibatkan orang lain untuk pencapaian tujuan.

H. Sudirman memberikan definisi dakwah sebagai usaha untuk merealisasikan ajaran Islam di dalam kenyataan hidup sehari-hari baik bagi kehidupan seseorang, maupun kehidupan masyarakat sebagai keseluruhan tata hidup bersama dalam rangka pembangunan bangsa dan umat manusia untuk memperoleh keridhaan Allah swt.

Esensi dakwah terletak pada upaya merealisasikan ajaran Islam dalam kehidupan pribadi dan bermasyarakat guna mendapatkan ridha Allah semata.

Oleh karena itu, manajemen dakwah adalah suatu proses dalam memanfaatkan sumber daya (insani dan alam) dan dilakukan untuk merealisasikan nilai-nilai ajaran Islam sebagai tujuan bersama.

Sains berarti ilmu teratur (sistematik) yang dapat diuji atau dibuktikan kebenarannya, atau dapat pula diartikan sebagai ilmu yang berdasarkan kebenaran atau kenyataan semata.

Pengertian tersebut dapat diketahui bahwa sains itu dapat pula berarti ilmu, dalam hal ini Amin Rais mempertegas bahwa sains adalah sebagai cabang studi yang berkenaan dengan perkenaan pengklasifikasian fakta-fakta dan khususnya dengan penetapan kaidah-kaidah umum yang bisa diuji. 
Sedangkan teknologi dapat diartikan sebagai kemampuan teknik yang berlandaskan ilmu pengetahuan, ilmu eksakta yang berdasarkan proses tehnis. Demikian pentingnya, sehingga dapat membentuk, mempengaruhi dan dapat membentuk dinamika masyarakat. Dalam kaitan ini Jalaluddin Rahmat mengemukakan bahwa semua teknologi adalah pedang bermata dua. Ia dapat digunakan untuk tujuan baik dan jahat sekaligus. Tetapi teknologi mutakhir menimbulkan manfaat yang banyak dan mudarat yang jauh lebih banyak.

\section{UPAYAMANAJEMEN DAKWAH DALAM MENGANTISIPASI DAMPAK NEGATIF SAINS DANTEKNOLOGI}

Perkembangan teknologi yang semakin maju begitu pesatnya, telah membawa dampak yang besar terhadap kehidupan umat manusia. Teknologi merupakan alat yang sangat ampuh untuk meningkatkan kualitas sumber daya alam dan sumber daya manusia, juga merupaka alat untuk menyebarkan ajaran agama Islam, terutama dalam menyampaikan kebenaran, untuk mengajak manusia ke jalan Tuhannya dan mencegah kemungkaran.

Sejalan dengan munculnya keritik atas dampak sains dan teknologi, telah lama pula orang sudah mengeritik dampak negatif yang ditimbulkannya sebagaimana yang dikemukakan oleh Mahdi Ghulsyani sebagai berikut:

1. 1.Sekularisme dan utilitarian yang memisahkan antara dunia material dan spiritual, memisahkan antara pengamat dengan yang diamati, antara subyek dan obyek, antara manusia dengan alam, yang akhirnya membawa kepada pemisahan antara fakta dan nilai, sehingga sifat ruhaniah dari alam dan bendabenda di dalamnya dihilangkan. Inilah yang disebut sekularisme.

2. 2.Sains dan teknologi tidak obyektif karena ia berkembang secara tidak ilmiah. Yang muncul pertama adalah gagasan dan fakta kemudian digunakan untuk mendukung hipotesis. Di samping itu sains dan teknologi tidak mengungkapkan kebenaran karena ia hanya melihat apa yang bisa dilihat oleh alatnya.

Selanjutnya Mahdi mengemukakan dampak dominasi rasionalisme dan empirisme. Hal ini merupakan suatu dampak yang tidak terlihat, karena muncul di antaranya pada pola pikir manusia yang pada gilirannya tentu saja pada prilakunya yang akan membawa kepada kecenderungan-kecenderungan budaya inderawi yakni budaya yang bersifat empiris, duniawi, sekuler, humanistik, pragmatis, utilitarian dan hedonistik.

Begitu dekatnya teknologi dalam kehidupan manusia, sehingga dapat dikatakan bahwa teknologi itu pada hakekatnya dapat berfungsi ganda. Untuk itulah Marwah Daut melihat bahwa teknologi selain membantu untuk memenuhi kebutuhan dasar, teknologi juga sesungguhnya bisa kian menyadarkan kita tentang kebesaran Allah swt., bisa mempertebal iman dan taqwa. Asal saja kita berangkat dengan asumsi dasar bahwa teknologi adalah bagian dari nikmat Allah bagi manusia. 
Guna lebih meningkatkan kualitas sumber daya manusia di masa datang, diperlikan adanya penguasaan sains dan teknologi bagi manusia, karena tanpa teknologi, manusia tidak akan maju.

Dewasa ini teknologi modern menyerbu manusia bagaikan air bah, penemuanpenemuan baru yang diharapkan bisa membuat hidup manusia lebih nyaman dan bahagia, sehingga tak heran jika penemuan baru membanjir setiap hari.

Teknologi modern yang kecanggihannya terus berkembang, mampu memecahkan problema hidup ketaraf hidup yang lebih baik/maju. Namun dalam waktu yang bersamaan, manusiapun menghadapi tantangan berat yang akan membawa manusia terjebak ke dalam proses penghambaan diri terhadap kemajuan ilmu pengetahuan dan teknologi serta perubahan-perubahan yang diakibatkannya. Dalam rangka menghadpi serbuan (ancaman nilai, keragaman pilihan hidup dan sejumlah janji kenikmatan duniawi), maka dakwah diharapkan bisa menjadi suluh dengan fungsi-fungsi sebagai berikut:

1. 1.Sebagai faktor pengimbang: mestinya dakwah bisa membantu kita untuk tidak hanya berkhidmat pada kehidupan duniawi yang dimegahkan oleh kemajuan teknologi canggih, tetapi tetap mengimbangkan kehidupan akhirat.

2. 2.Sebagai penyaring: ia diharapkan dapat membantu kita untuk dapat menentukan pilihan terhadap nilai-nilai yang lebih manusiawi dan islami dari arus perubahan yang terjadi akibat penemuan dan penerapan berbagai teknologi modern.

3. 3.Sebagai pengarah: dakwah diharapkan tidak mengalami proses kebingungan dalam peradaban dunia yang pebuh dinamika.

4. Disamping itu terdapat prinsip-prinsip manajemen dakwah yang kiranya diharapkan mampu menepis laju perkembangan dampak negatif yang ditimbulkan oleh sains dan teknologi.

Prinsip manajemen dakwah yang dimaksudkan adalah:

1. Memperjelas secara gamblang sasaran-sasaran ideal.

2. Sasaran ideal yang akan dituju dakwah perlu diperjelas, agar kondisi umat Islam (yang sedang diliputi dengan sains dan teknologi) yang diharapkan dapat tercapai. Sasaran ideal ini penting, sebab dengan jelasnya sasaran akan memudahkan pelaksanaan perencanaan, pengorganisasian pelaksanaan dan pengawasan terhadap jalannya upaya manajemen dakwah mengatur strategi, sehingga dapat lebih mudah pencapaian tujuan.

3. Merumuskan masalah pokok umat Islam

Memperhatikan dampak negatif dari sains dan teknologi serta banyaknya jenis teknologi yang muncul, menyebabkan banyaknya masalah yang melanda umat Islam. oleh karena itu, perlu dirumuskan masalah-masalah pokok yang memperhitungkan skala prioritas dan tetap mempertimbangkan masalah waktu, biaya dan tenaga yang tersedia.

4. Merumuskan materi dakwah 
Setelah dirumuskan secara tepat sasaran ideal yang dilengkapi dengan rumusan masalah pokok, maka yang perlu yang perlu dipertimbangkan selanjutnya merumuskan materi dakwah.

Materi dakwah yang dipersiapkan adalah harus disesuaikan dengan kondisi masyarakat, sebab ketidak singkronan dalam penyusunan materi dakwah dapat menyebabkan timbulnya masalah baru di masyarakat.

Masalah yang perlu diperhatikan adalah tata urutan materi dakwah dan dilaksanakan secara sistimatis, sehingga dalam suatu masalah betul-betul tuntas mulai akar permasalahan sampai penyelesaian maslah. Dengan demikian materi dakwah yang disajikan tidak terkesan monoton dan asal tersajikan, tetapi betul-betul mencabut permasalahan dan tidak sekedar mengobati gejala-gejalanya.

5. Evaluasi kegiatan

Pada akhirnya, prinsip manajemen dakwah adalah evaluasi kegiatan, hal ini dimaksudkan agar apa yang tidak dilaksanakan dan diupayakan oleh manajemen dakwah dievaluasi pelaksanaannya, sehingga bila terjadi selisih antara planning dengan actuating, maka diadakan perbaikan dan pelurusan atas kekurangan yang dialami.

Evaluasi ini menjadi bahan pemikiran terhadap hasil kerja, sehingga dapat diketahui tingkat keberhasilan dan tingkat kegagalandlm pelaksanaan kegiatan.

Ketiga fungsi dan prinsip manajemen dakwah tersebut kiranya menjadi acuan dalam upaya mengantisipasi dampak negatif yang ditimbulkan oleh sains dan teknologi guna tercapainya tujuan dakwah yaitu:

1. Mengajak umat Islam yang sudah memeluk Islam untuk selalu meningkatkan taqwanya kepada Allah swt.

2. Membina mental agama (Islam) bagi kaum yang masih muallaf.

3. Mengajak umat manusia yang belum beriman agar beriman kepada Allah (memeluk agama Islam).

4. Mendidik dan mengajar anak-anak agar tidak menyimpang dari fitrahnya.

5. Memperhatikan fungsi dan prinsip manajemen dakwah tersebut, dikaitkan dengan tujuan dakwah di atas, maka diharapkan dapat menepis lajunya perkembangan dampak negatif yang ditimbulkan oleh sains dan teknologi, terutama pada perkembangan anak dan umat Islam seluruhnya, sehingga manusia dapat terbebas dari segala dampak negatif tersebut.

Dalam menyikapi kemajuan ilmu pengetahuan dan teknologi, maka manajemen dakwah senantiasa mengantisipasi berbagai tantangan yang ada. Oleh karena itu, manajemen dakwah senantiasa memperhatikan dan melaksanakan kegiatan dakwah yang berkifrah ke depan, yaitu:

1. Orientasi dakwah harus lebih mengacu pada penunjukan dan pembuktian kemahabesaran Allah swt., cara yang bisa diterima akal sehat. Untuk itu 
kajian syariat perlu disejajarkan dengan kajian non syariat. Kajian non syariat bisa merujuk kepada kemajuan ilmu pengetahuan dan teknologi dalam memahami atau menguasai sunnatullah.

2. Kecintaan kepada sesama manusia juga merupakan inti kegiatan dakwah. Kecintaan ini dapat dicapai lewat keyakinan bahwa kita semua sesungguhnya bersaudara, dengan demikian kita harus mengenal, pengenalan tersebut harus dimanifestasikan dalam berbagai bentuk hubungan yang positif.

Kedua hal tersebut menggambarkan bahwa manajemen dakwah akan terasa lebih fungsional dan lebih berdaya guna dalam mengembangkan benih-benih pengenalan dan kecintaan kepada Allah, dengan sujud dan berserah diri kepada-Nya.

Memperhatikan pesatnya perkembangan ilmu pengetahuan dan teknologi di zaman sekarang ini, maka manajemen dakwah diharapkan lebih mampu mengefektifkan tujuan.

Oleh karena itu, hal-hal yang perlu dilakukan oleh manajemen dakwah dalam mengantisipasi dampak negatif perkembangan sains dan teknologi adalah:

1. Makna komunikator harus diperluas; kalau selama ini cenderung melihat komunikator hanyalah mereka yang disebut ulama atau muballig, maka makna itu sebaiknya diperluas. Harus dipersiapkan bahwa sesungguhnya umat Islam mempunyai tugas kedamaian.

2. Isi pesan perlu diperluas; isi pesan dakwah diharapkan tidak hanya merujuk ke dalam Alquran dan sunnah, tetapi juga pada sumber dinamis berupa universium langit dan bumi serta segala yang ada di antara keduanya.

3. Media perlu diperluas maknanya; semua jenis media dakwah dapat dimanfaatkan untuk tujuan dakwah.

4. Audience perlu diperluas maknanya; perluasan audience ini dilakukan dengan berbagai pendekatan atau metode yang berbeda-beda dengan jangkauan dakwah yang sesuai, namun memerlukan manajemen yang baik dan penanganan yang profesional.

5. Dengan perluasan makna tersebut berarti terkandung pemanfaatan teknologi secara positif dan mengalihkan perhatian pengguna teknologi kepada perluasan makna, seperti pengakuan kemahabesaran Allah swt., yang telah membimbing manusia sehingga mampu membuat teknologi yang canggih dan dapat memperpendek jarak yang jauh serta dapat mengganti tenaga manusia dengan tenaga mesin dan sebagainya.

Oleh karena itu, Marwah Daut mempertegas kembali prinsip yang perlu dilakukan oleh pelaksana dakwah dalam rangka mengantisipasi dampak negatif perkembangan sains dan teknologi yaitu:

1. Dakwah sebaiknya disampaikan secara persuasif informatif, melayani, bukan instruktif dan membebani apalagi mengancam, karena itu dakwah disampaikan secara lemah lembut.

2. Dakwah sebaiknya disampaikan di semua waktu, tempat dan kesempatan. 
3. Kegiatan dakwah sepatutnya dilakukan dengan menyebarkan berita kebenaran tanpa harus menjelek-jelekkan pihak lain.

4. Kegiatan dakwah tidak perlu dilihat sebagai gerakan untuk mencapai hasil hanya sekali gerak.

5. Dakwah sudah saatnya membantu kita menemukan pesan-pesan lain yang tercantum dalam bentuk peribadatan moral.

6. Manajemen dakwah perlu ditingkatkan.

Dengan perlakuan pelaksana dakwah tersebut bila diterapkan dengan baik, maka dampak yang akan ditimbulkan oleh perkembangan sains dan teknologi dapat diatasi dengan baik. Untuk itulah peran aktif umat Islam secara keseluruhan sangat diharapkan dalam rangka meningkatkan mutu dakwah dimasa depan.

\section{KESIMPULAN}

Berdasarkan dari uraian yang lalu, maka pada uraian ini penulis mengemukakan kesimpulan sebagai berikut:

1.Perkembangan sains dan teknologi dewasa ini mampu merubah pola pikir dan pola sikap umat manusia. Perubahan itu dapat membawa kepada masalah-masalah yang bersifat positif dan dapat pula berbentuk negatif.

2.Umat Islam dalam melihat perkembangan sains dan teknologi, tidak boleh memandang sebelah mata, tetapi di samping dituntut untuk dapat menguasai teknologi, juga dituntut ia mampu mengendalikan dampak negatif yang ditimbulkannya. Oleh karena itu, umat Islam tidak boleh jauh dari teknologi, tetapi harus merangkul dengan mengisi pesan-pesan yang bernilai islami.

3.Upaya yang perlu dilakukan oleh manajemen dakwah dalam mengantisipasi dampak negatif yang ditimbulkan oleh sains dan teknologi adalah dengan memperhatikan prinsip-prinsip manajemen dakwah, disamping memberi makna yang tepat tentang makna komunikator, media dakwah dan audience yang perlu dikembangkan pada makna yang lebih luas, berupa makna materi, media dan pelaksanaan dakwah dengan merujuk pada kebutuhan dan tuntutan zaman.

Manajemen dakwah ditempuh perkembangan sains dan teknologi dapat lebih leluasa mengembangkan dan mengatur strategi dakwah pada sasaran ideal dakwah, sehingga dapat memudahkan pencapaian tujuan. Disamping itu, untuk memakan laju perkembangan dampak negatif sains dan teknologi diperlukan keterlibatan berbagai pihak secara menyeluruh, agar seluruh akar permasalahan manajemen dakwah dapat terselesaikan. 


\section{DAFTAR PUSTAKA}

Ghulsyani, Mahdi. Filsafat Sains Menurut Alquran. Bandung: Mizan, 1991.

Hafiduddin, Didin. dalam Adi Sasono dkk, Solusi Islam atas problematika Umat: (Ekonomi, Pendidikan dan Dakwah). Cet. I; Jakarta: Gema Insani Press, 1998.

Ibrahim, Marwah Daud. Teknologi Emansipasi dan Transendensi. Bandung: Mizan, 1994.

Nasr, Sayyed Hussein. Menjelajahi Dunis Modern. Bandung: Mizan, 1993.

Rahmat, Jalaluddin. Islam Alternatif. Bandung: Mizan, 1991.

Rais, M. Amin. Cakrawala Islam, Antara Cita dan Fakta. Bandung: Mizan, 1991.

Sudirman, H. Problematika DakwahIslam di Indonesia. Jakarta: Forum Dakwah, Pusat Dakwah Islam Indonesia, 1972.

Syukir, Asmuni. Dasar-Dasar Strategi Dakwah Islam. Surabaya: al-Ikhlas, 1983.

Tim Penyusun Kamus Pusat Pembinaan dan Pengembangan Bahasa, Kamus Besar BahasaIndonesia. Jakarta: Balai Pustaka, 1989. 